\title{
Dwarf varieties and rootstocks - the basis for creating intensive pear gardens in Central Russia
}

\author{
Evgeny Dolmatov*, and Igor Semin \\ Russian Research Institute of Fruit Crop Breeding (VNIISPK), Zhilina village, Oryol District, Oryol \\ Region, the Russian Federation
}

\begin{abstract}
The interim results of many years of work on the creation of pear varieties - genetic dwarfs and dwarf rootstocks of an intensive type with a high adaptive potential suitable for setting intensive gardens in the conditions of the Central region of Russia are presented. At the first stage in the creation of intensive pear varieties obtained from crossing of highly winter-resistant and disease-resistant donors of various genetic origins with donors of monogenic determined dwarfism, high winter-resistant dwarf donors with group resistance to diseases were obtained. Among the seedlings obtained, promising forms were noted - 1-4-38, 1-6-74, 1-6-79, 1-6-83, which have a number of economically useful traits that are valuable for further work in the direction of obtaining super-intensive pear varieties. Preliminary data on the assessment of common quince as an intensive pear rootstock are given. The high winter-hardiness of common quince plants in the conditions of the Orel region is shown, the possibility of selected forms to propagate well with green cuttings and provide a high yield of homogeneous planting material is determined. High indicators of seed productivity and rootstock yield were noted in comparison with green cuttings. The preliminary results of the assessment of common quince compatibility with some pear varieties in nursery are presented. The prospects of the apple-pear hybrid as an intermediary in incompatible scion-rootstock combinations with dwarf rootstocks of VNIISPK breeding are shown.
\end{abstract}

\section{Introduction}

In the world, more than 20 million tons of pear fruits are produced annually, which is $2-3$ $\mathrm{kg}$ per capita per year. China and Argentina are the leading producers, which are the leaders in the world market of pear fruit production [1]. The United States and the European Union countries are after them, producing up to 700-800 thousand tons per year. Russia occupies only the 25th place in the world with a production volume of 65-68 thousand tons of pear fruit per year or $0.45 \mathrm{~kg}$ per capita, which clearly does not meet the needs of the population. The main cultivation areas are concentrated in the southern regions of Russia and primarily in the North Caucasus, where more than $90 \%$ of all pear plantations in the country are

\footnotetext{
*Corresponding author: dolmatov@vniispk.ru
} 
located. In Central Russia, pear culture has no industrial significance [2]. This is largely due, firstly, to the lack of highly productive, early-fruiting pear varieties that have a long shelf life and high commercial and taste qualities of fruits suitable for production using intensive technologies; secondly, to the tallness and non-technological nature of most pear varieties; and thirdly, to the lack of intensive rootstocks that can restrain growth and accelerate the entry of varieties into the time of industrial fruiting. As a result of many years of breeding work, pear varieties have been obtained that are successfully cultivated in gardens and are in high demand among the population, but only a few of them are of industrial importance, especially given the requirements of modern gardening and production intensification. Therefore, the priority task of modern breeding is the breeding of highly productive, early-fruiting pear varieties of restrained and dwarf habitus with high productivity potential and resistance to adverse environmental factors. As for rootstocks, today in the Central Chernozem region, pear seedlings are produced using ordinary pear seedlings, which do not meet the requirements of modern gardening. [3; 4]. They have a tap-root system with poor regeneration, their leaves are often affected by diseases in epiphytotic years up to 5 points, the scions are characterized by strong growth and enter the fruiting season late, and the plantings are often sparse and unproductive $[5 ; 6 ; 7 ; 8 ; 9]$. The use of vegetative propagated rootstocks, especially those introduced from other regions and countries, does not give positive results due to the low potential of resistance to the conditions of the central part of Russia. Therefore, the problem of creation of highly productive commercial pear gardens of intensive and super-intensive type in terms of the CCR with the use of high-yielding dwarf varieties of pear and dwarf rootstocks is very relevant and important.

\section{Materials and methods}

The purpose of the work is to create dwarf pear varieties with high productivity and adaptive potential and intensive dwarf rootstocks suitable for setting up gardens in Central Russia. The study was performed at the laboratory of plant breeding and cultivar of pear and non-traditional seed crops of the FSCSI VNIISPK from 2000 to the present, in accordance with the Program and methods of fruit, berry and nut crops breeding (1995) and the Program and methodology of fruit, berry and nut crops variety study (1999). The object of research is the pear seedlings obtained by crossing of donors of high winter hardiness and resistance to diseases with monogenic determined dwarfism donors - descendants of the 4th generation from Nain Vert variety, heterozygous for dwarfism gene (D), as well as selected forms of common quince of VNIISPK breeding, showing the high adaptive capacity in terms of the Orel region.

\section{Results and discussions}

\subsection{Creating intensive pear varieties with high productivity}

The original form containing the dwarfism gene and being a descendant in the 4th generation descended from the European Nain Vert variety is used in the work on the production of industrial pear varieties. These pears have a dwarf habitus controlled by the $\mathrm{D}$ gene and are highly productive. The initial female parents in the work were pear varieties and forms with high winter hardiness, derived from the common pear (Voskovka, seyanets Voskovki) and Ussurian pear (Vidnaya, grusha ot Somova, Pamyati Yakovleva, Larinskaya, Duymovochka and others). Pollination was performed with a mixture of pollen 
obtained from dwarf pear forms derived from the Nain Vert variety, which have a high marketable value and good fruit taste.

The result of the first stage of the breeding program for the creation of dwarf pear varieties was the production of highly winter hardiness dwarf pear donors with group resistance to diseases (Fig. 3). The height of these seedlings at the age of 10 years varied from 1.5 to 2.5 $\mathrm{m}$ (Fig. 1). All of them are of considerable interest for subsequent breeding work. Among the obtained seedlings, the selected form DK-2 is actively used in breeding work, which has a number of valuable economic and useful trains (Fig. 2), including dwarfism, sufficient winter hardiness, group resistance to diseases, high marketable value of fruits and early fruitfulness [10].

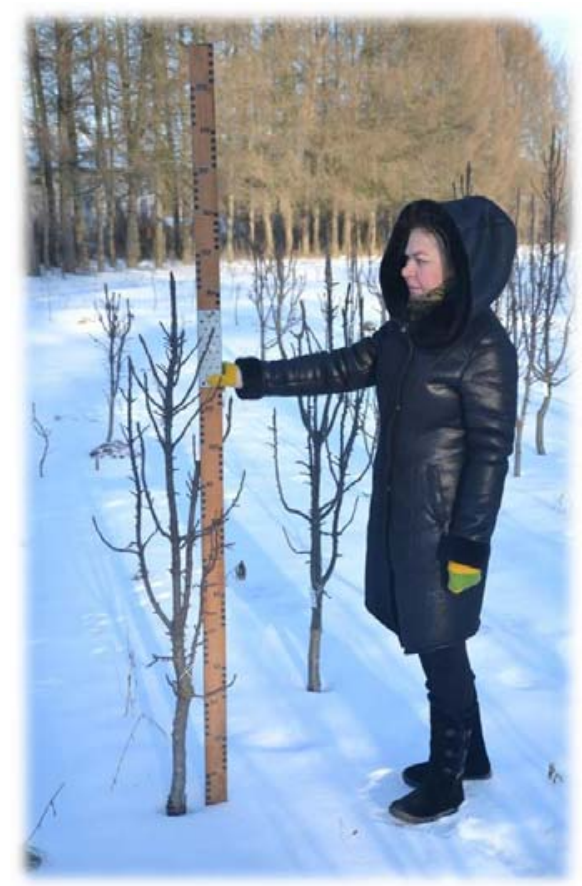

Fig. 1. Height of seedlings at 10-year-old age [11]

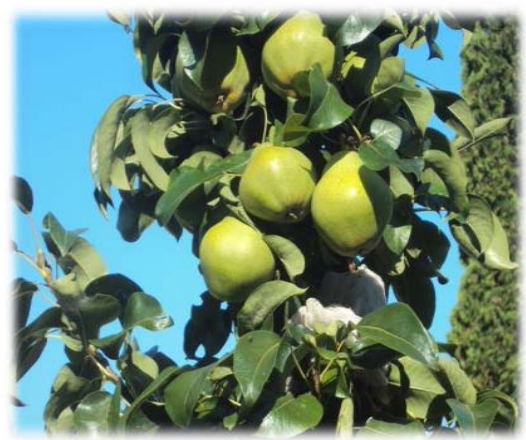

Fig. 2. Selected form DK-2 [11]

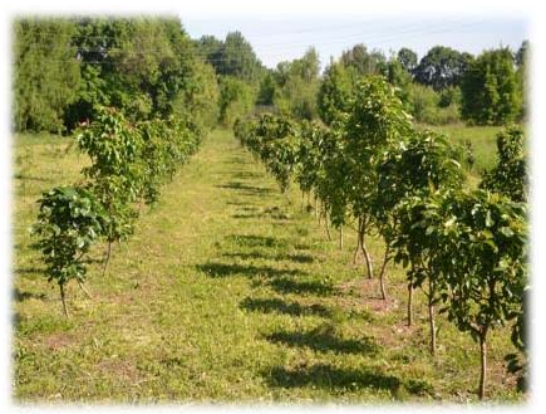

Fig. 3. Pear dwarf garden [11]

In 2020, 2 pear seedlings were allocated to the elite for a complex of economically valuable traits - a dwarf seedling 1-4-38 and a seedling with a restrained tree growth 1-7-22 (Fig. 4 and 5). 


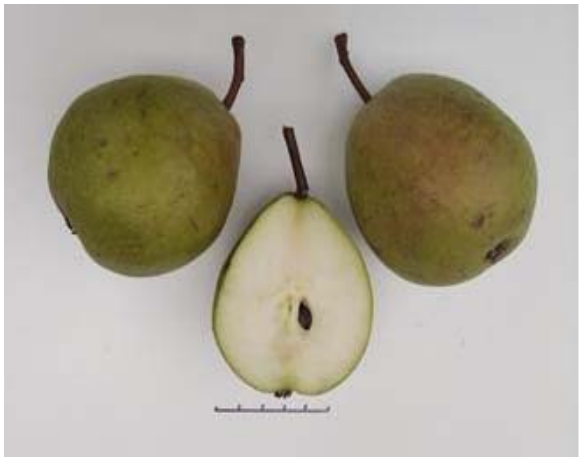

Fig. 4. Fruits of the elite seedling 1-4-38

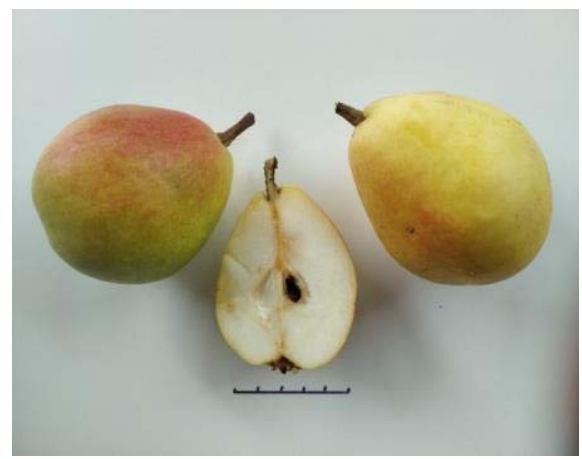

Fig. 5. Fruits of the elite seedling 1-7-22

ELS 1-4-38. The ripening period is autumn. Dwarf tree with monogenic trait control. Heterozygote - Dd. The height of the plants at the age of 12 years was $175 \mathrm{~cm}$, the crown diameter was $90 \mathrm{~cm}$. The trees are characterized by sufficient winter hardiness. During the years of observations (from 2005 to 2020), no significant freezing was observed. High resistance to scab, brownness and Septoria blight. In the years of epidemics it is greatly affected by the European pear rust. Fruits of medium size, weighing 120-150 g greenyellow, wide-pear-shaped. The pulp is semi-oily, of very good sweet taste with a slight sour taste (taste 4.2-4.3 points). It is of great interest for further use in dwarf varieties breeding and study in gardens with thickened planting scheme $(2.5 \times 1 \mathrm{~m}, 3 \times 1 \mathrm{~m}$ and $4 \times 1 \mathrm{~m})$

ELS 1-7-22. Summer ripening seedling. A tree of moderate growth, early maturing, resistant to scab, brownness and Septoria blight. It is affected by European pear rust to a moderate extent. Fruits weighing 130-140 g, short-shaped, yellow with a blush. The flesh is semi-oily, sweet with a slight nutmeg taste, of good taste.

Also, 4 selected pear seedlings were selected for a complex of economically valuable traits - 1-7-5, 1-6-74, 1-6-79, 1-6-83.

Selected seedling 1-6-74. Dwarf seedling of the autumn ripening period. At the age of 12 , the tree did not exceed $180 \mathrm{~cm}$ in height and crown diameter of $100 \mathrm{~cm}$. In the conditions of the Orel region, it is quite winter-hardy, resistant to scab, brownness and Septoria blight. In the years of epidemics it is affected the European pear rust to a moderate extent. Fruit weight $130 \mathrm{~g}$, pear-shaped. The main fruit color is greenish-yellow, the cover color - in the form of weak blurred brownish blush. The pulp is semi-oily, juicy, of very good sweet taste with a slight sour taste. The fruits can be stored for 20-30 days. It is highlighted for its good taste, dwarf habitus, sufficient winter hardiness and early maturity. It is of interest for further study in gardens with a thickened planting scheme $(2.5 \times 1 \mathrm{~m}, 3 \mathrm{x}$ $1 \mathrm{~m}$ and $4 \times 1 \mathrm{~m}$ ) and for use in breeding.

Selected seedling 1-6-79 Dwarf seedling of early-autumn maturity. A 12-year-old tree with a height of $170 \mathrm{~cm}$, resistant to scab, brownness and Septoria blight. It is affected by European pear rust to a moderate extent. Fruits weighing 120-130 g, pear-shaped, greenyellow. The flesh is semi-oily, sweet with a slight sourness near the seed chambers, of very good taste. It is highlighted for its good taste, early-maturity, autumn ripening period, dwarfism and winter hardiness. It is of interest for further study in gardens with a thickened planting scheme $(2.5 \times 1 \mathrm{~m}, 3 \times 1 \mathrm{~m}$ and $4 \times 1 \mathrm{~m})$ and for use in breeding.

Selected seedling 1-6-83. Dwarf seedling of the autumn ripening period. A 12-year-old tree with a height of $160 \mathrm{~cm}$, resistant to scab, brownness and Septoria blight. It is affected by European pear rust to a moderate extent. Fruits weighing 130 g, short-pear-shaped, yellowish-green. The flesh is semi-oily, sweet with a slight sourness near the seed chambers, of very good taste. It is highlighted for its good taste, early-maturity, autumn 
ripening period, dwarfism and winter hardiness. It is of interest for further study in gardens with a thickened planting scheme $(2.5 \times 1 \mathrm{~m}, 3 \times 1 \mathrm{~m}$ and $4 \times 1)$ and for use in breeding. The material obtained in the course of this work is an important step towards the creation of highly productive pear varieties for intensive gardening in Central Russia.

\subsection{Creation of pear rootstocks, for the production of fruits using intensive technologies}

Work on the creation of intensive type dwarf rootstocks for pear varieties is carried out using common quince. In the world of fruit growing, it is successfully and actively used as a dwarf rootstock, but due to the low winter hardiness of plants, it could not be used in Russia. Breeding of dwarf pear rootstocks using common quince in VNIISPK has been conducted since 1993, as a result of which winter-hardy forms were obtained, with a high reproduction rate of green cuttings and seeds and showed good compatibility with pear varieties in the nursery. Dwarf rootstocks of VNIISPK breeding are of considerable interest in further breeding work [12; 13].

Common quince is a thermophyte plant and is not peculiar to Central Russia. Taking into account the relatively mild weather conditions of the winter of 2018-2019, in comparison with long-term observations, the plants of the common quince overwintered without any serious damage (Table 1). Minor frost-cracks (no more than 1 point) were observed on the surface tissues and most likely were obtained in the second half of the winter period, when plants after thawing could not withstand a sharp temperature drop. However, in general, the plants recovered well during the season.

The winter 2019-2020 was characterized by unusually warm periods and fairly long low positive temperatures, as well as a small amount of precipitation. Frosts typical for the climatic conditions of the central part of Russia in 2019-2020 were not observed. As a result, all the plants had a healthy appearance and normal regrowth without showing symptoms of damage by low temperatures and flowered more abundantly than ever.

Table 1. Assessment of winter hardiness of common quince in the field conditions (visual method) and in the laboratory (method of artificial freezing of annual growth)

\begin{tabular}{|c|c|c|c|}
\hline & $\begin{array}{l}2018- \\
2019\end{array}$ & $\begin{array}{l}2019- \\
2020\end{array}$ & $\begin{array}{l}\text { Average } \\
\text { for } \quad 2 \\
\text { years }\end{array}$ \\
\hline \multicolumn{4}{|l|}{ Visual assessment method } \\
\hline Degree of bark freezing, point & 1 & 0 & 0.5 \\
\hline Wood freezing, point & 0 & 0 & $\mathbf{0 . 0}$ \\
\hline Crown branches freeze-out, point & 1 & 0 & 0.5 \\
\hline Total degree of freezing, point & 1 & 0 & 0.5 \\
\hline \multicolumn{4}{|l|}{ Laboratory assessment method } \\
\hline $\begin{array}{l}\text { Artificial freezing temperature for the } 4 \text { components of } \\
\text { winter hardiness - } \\
1 \mathrm{~K}-30^{\circ} \mathrm{C} \text { : } \\
2 \mathrm{~K}-40^{\circ} \mathrm{C} \text { : } \\
3 \mathrm{~K}-25^{\circ} \mathrm{C} \text { : } \\
4 \mathrm{~K}-35^{\circ} \mathrm{C}\end{array}$ & $\begin{array}{l}0.8 \\
3.6 \\
2.7 \\
4.4 \\
\end{array}$ & $\begin{array}{l}1.1 \\
4.0 \\
2.2 \\
4.0\end{array}$ & $\begin{array}{l}1.1: \\
3.8: \\
2.5: \\
4.2\end{array}$ \\
\hline
\end{tabular}

A laboratory method for frost resistance assessment of annual growth of common quince by exposure to simulated under controlled conditions critical temperature for 4 components of winter hardiness, corresponding to the climatic characteristics of Central Russia, showed small damage to the tissues of stems and buds $-30{ }^{\circ} \mathrm{C}(1 \mathrm{~K})$, similar to the effects of low temperatures in the field conditions at the beginning of winter. During this period, the plants after autumn hardening are in a state of organic rest (Table 1). When exposed to a temperature of $-40^{\circ} \mathrm{C}$, corresponding to the maximum frost resistance of plants 
in the state of organic rest end $(2 \mathrm{~K})$, there is significant damage to the buds, which budding was not observed. In the middle of winter at $-25^{\circ} \mathrm{C}(3 \mathrm{~K})$, which corresponds to the temperatures of January-February, when the plants are in a state of induced dormancy, slight damage to annual shoots is also noted. However, despite the damage, the buds grew well. The most severe damage to the tissues and buds of the annual quince growth was revealed during freezing at $-35^{\circ} \mathrm{C}(4 \mathrm{~K})$, when in a state of induced dormancy, the plants can restore frost resistance during re-hardening after thaws at the end of the winter. However, studies have shown that during this period, plants are most severely damaged by frost. Most of the buds die, and the remaining ones showed weak regrowth. However, it should be noted that in practice, severe winters in Central Russia are quite rare.

VNIISPK also carried out a lot of work on the study of vegetative reproduction of common quince, the method of green cuttings and the development of clonal rootstocks in the nursery [12].

Pear seedlings on the clonal rootstock 32A-1-29 have a more powerful growth, a greater number of branches and a higher yield of standard planting material than seedlings obtained using pear seedlings as a rootstock (Fig. 8).

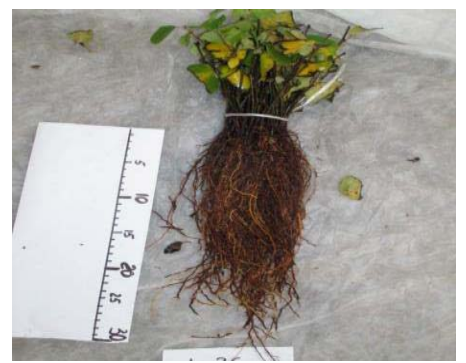

Fig. 6. Rooted green cuttings of common quince

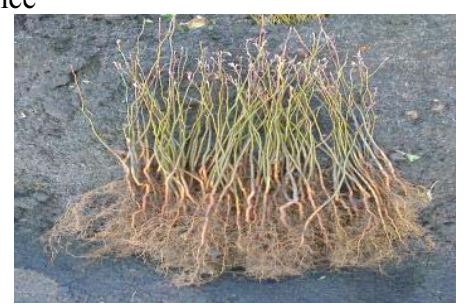

Fig. 7. Seedlings of common quince

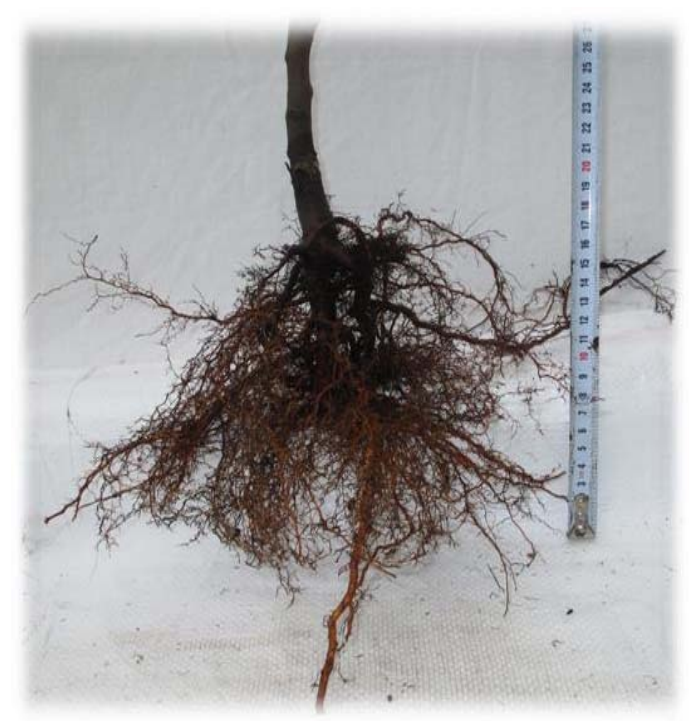

Fig. 8. Root system of pear seedlings grafted on rootstock 32A-1-29

It is known that the use of clonal rootstocks makes it possible to set uniform pear plantings in the garden in terms of plant height, size and fruits quality, other economic and useful indicators, which is a priority in intensive gardening. However, in practice, seed propagation is technologically simpler, cheaper, and in a similar period of time allows to grow many times more rootstocks than with clonal reproduction (Fig. 6 and 7). 


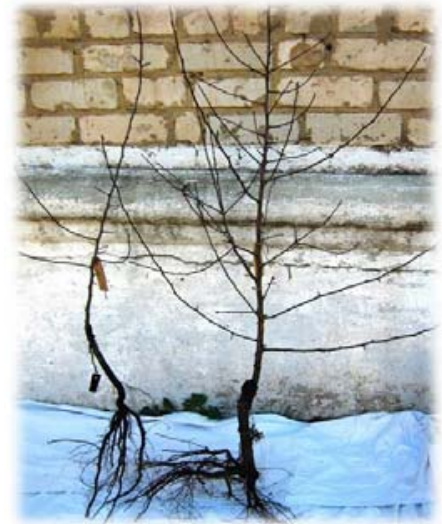

Fig. 9. Pear seedlings (on the left wild pear rootstock; on the right common quince rootstock)

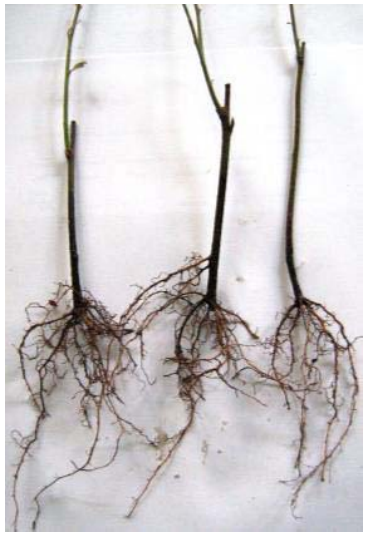

Fig. 10. Clonal rootstock common quince. (green cuttings)

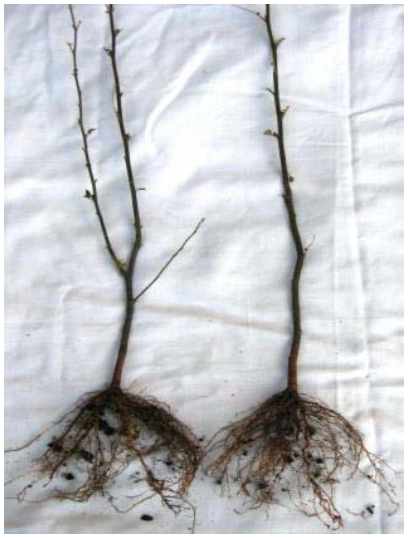

Fig. 11. Seed rootstock common quince.

Research data show that the potential yield of rootstocks from a single mother bush in seed propagation is 8-10 times higher than in clonal reproduction (Tables 2 and 3). In addition, rootstocks of seed origin have a more powerful root system, thanks to the initially developed skeletal roots and main root. The roots of clonal rootstocks are formed from the vegetative part of plants and have more lateral root system than seed rootstocks, which often causes the need for supporting structures when setting a garden with their use. (Figures 10 and 11). Therefore, as an alternative to clone rootstocks, the laboratory studies the seed rootstocks of common quince used as a dwarf rootstock for pears.

Table 2. Seed propagation method

\begin{tabular}{|l|l|}
\hline $\begin{array}{l}\text { Productivity, pcs. } \\
\text { seeds/shrub }\end{array}$ & 2880 \\
\hline Germination rate, \% & 77.8 \\
\hline Yield of seedling rootstock, \% & 91.0 \\
\hline Growth length of rootstocks, cm & 21.0 \\
\hline Number of skeletal roots, pcs. & 3.3 \\
\hline Length of skeletal roots, cm & 14.0 \\
\hline Root collar diameter, mm. & 4.5 \\
\hline $\begin{array}{l}\text { Potential yield of rootstocks, } \\
\text { pcs./shrub }\end{array}$ & $\begin{array}{l}1700- \\
1900\end{array}$ \\
\hline
\end{tabular}

Table 3. Vegetative reproduction

\begin{tabular}{|l|l|}
\hline $\begin{array}{l}\text { Productivity, pcs. } \\
\text { cuttings/shrub }\end{array}$ & 370 \\
\hline Rooting ability, \% & 76.9 \\
\hline Clonal rootstocks yield, \% & 80.7 \\
\hline Growth length of rootstocks, cm & 62.2 \\
\hline Number of skeletal roots, pcs. & 4.9 \\
\hline Length of skeletal roots, cm & 17.0 \\
\hline Root collar diameter, mm. rootstocks, & 6.2 \\
\hline $\begin{array}{l}\text { Potential yield of } \\
\text { pcs./shrub }\end{array}$ & 230 \\
\hline
\end{tabular}

In the course of the work, we have already obtained sufficiently winter-hardy selected forms of common quince with high seed productivity, which are of considerable interest in further study in the direction of obtaining seed rootstocks for pears.

Quince and pear belong to different genera, so in varietal-rootstock combinations, the phenomenon of incompatibility of the grafted components is often found. Identifying positive accretions is the most important task in work with rootstocks. Signs of incompatibility can be found already in the nursery. First of all, the variety accretion with the rootstock is determined by three main indicators [12]: Spot disease - weak annual growth, small leaves and the formation of necrotic areas on rootstock wood and bark; rootstock starvation - usually occurs in late summer in a relatively early end of the sustained growth of the shoots, redness and scion defoliation happening ahead of time, and the third indicator is manifested by the formation of callosity in the accretion area and loose connection of scion and rootstock at the site of inoculation. The sign may not appear immediately and the plants may initially have an active and strong progressive growth. 
However, after some time, the shoots may break off in the places of accretion. In this case, the fracture often has a smooth structure, without fibers.

The results of preliminary studies conducted in the VNIISPK nursery showed good accretion with common quince of 6 pear varieties of industrial interest for the Central Chernozem region: Alaya, Belorusskaya Pozdnyaya, Yeseninskaya, Muratovskaya, Pamyati Yakovleva, Tyutchevskaya, etc. $[13 ; 14]$. A strong accreting with the rootstock and active growth of the scion were revealed already in the nursery, in all variety-rootstock combinations.

Satisfactory accretion with the rootstock was shown by the varieties Annushka and Pamyatnaya, in which although there were no obvious signs of incompatibility, but not a single seedling with strong annual growth was found in the entire grown batch, that meets the GOST R standards (Table 4). At the beginning of the growing season, varieties Chizhovskaya and Krasavitsa Chernenko had an active progressive growth of shoots, the intensity of which by the second half of summer significantly decreased in the variants with common quince, in contrast to the variety-rootstock combinations with pear rootstock. Probably, there may be a partial incompatibility with common quince for these varieties, expressed in the inability of individual tissues to fully assert due to differences in biological structure and metabolism.

Table 4. Compatibility of pear varieties with common quince $[12 ; 13]$

\begin{tabular}{|c|c|c|}
\hline $\begin{array}{l}\text { Good assertion with } \\
\text { common quince }\end{array}$ & $\begin{array}{c}\text { Satisfactory } \\
\text { assertion with } \\
\text { common quince }\end{array}$ & $\begin{array}{l}\text { Unsatisfactory assertion } \\
\text { with common quince }\end{array}$ \\
\hline $\begin{array}{l}\text { Yeseninskaya } \\
\text { Tyutchevskaya } \\
\text { Muratovskaya } \\
\text { Alaya } \\
\text { Pamyati Yakovleva } \\
\text { Belorusskaya } \\
\text { Pozdnyaya } \\
\text { Inset rootstock - apple- } \\
\text { pear hybrid No. } 818\end{array}$ & $\begin{array}{l}\text { Annushka } \\
\text { Pamyatnaya } \\
\text { Chizhovskaya } \\
\text { Krasavitsa Chernenko }\end{array}$ & $\begin{array}{l}\text { Orlovskaya Krasavitsa } \\
\text { Orlovskaya Letnyaya } \\
\text { Skorospelka iz } \\
\text { Michurinska } \\
\text { Rusanovskaya } \\
\text { Inset rootstock - seedling } \\
\text { of Ussurian pear No. } 20 \text { - } \\
11\end{array}$ \\
\hline
\end{tabular}

Clear signs of incompatibility in variety-rootstock combinations with the common quince are showed by pears Orlovskaya Krasavitsa, Orlovskaya Letnyaya, Skorospelka iz Michurinska, Rusanovskaya and winter-hardy seedling of apomictic pear of Ussurian origin No. 20-11, which was considered as a winter-hardy insert rootstock (Table 4). In all variants, there are callosities and breaks in accretion areas, earlier change in leaf color and leaf-fall, starting from the upper part of the shoots, as well as the appearance of shoot in the rootstock area. There was a change in scion sprout bark color to shades of red in the second half of summer and a weak annual sprouting. Obviously an intermediary (inserted rootstock) is needed for the cultivation of these varieties using dwarf rootstocks of the VNIISPK breeding.

Apple-pear hybrid No. 818 showed the best assertion with common quince and intensive growth already in the nursery. Active branching of the annual growth was observed throughout the growing season until the leaf fall. No signs of incompatibility were found. Based on the results obtained, it can be considered as a compatible insert (intermediary) for pear varieties incompatible with quince (Fig.9). In addition, the hybrid itself is a weakly growing rootstock and has a fairly high winter hardiness in the middle zone of Russia, which gives it a certain advantage. 


\section{Conclusion}

During the implementation of the breeding program for the creation of intensive dwarf pear varieties, highly resistant forms with group resistance to diseases, dwarf crown habitus and good fruit taste were obtained, which are of considerable interest for use in breeding and industrial study in intensive type gardens with a planting density of 2500-4000 trees per hectare: DK-2, 1-4-38, 1-6-74, 1-6-79 and 1-6-83.

For the second direction satisfactory winter-hardiness of common quince plants in the conditions of the Orel region is shown, the possibility of selected forms to propagate well with green cuttings and provide a high yield of homogeneous planting material is determined. High seed productivity and rootstock yield were noted in comparison with green cuttings. Preliminary positive results of good compatibility of pear varieties in nursery conditions were obtained: Yeseninskaya, Tyutchevskaya, Muratovskaya, Alaya, Pamyati Yakovleva and Belorusskaya Pozdnyaya, having an industrial interest for Central Russia. There are 4 varieties of pears - Orlovskaya Krasavitsa, Orlovskaya Letnyaya, Skorospelka iz Michurinska, Rusanovskaya incompatible with common quince. The high compatibility of the apple-pear hybrid proposed as an intermediary in incompatible varietyrootstock combinations with the common quince was revealed.

\section{References}

1. V.S. Girichev, Bulletin of the Russian Academy of Agricultural Sciences, 1, 95 (2009)

2. R.D. Isaev, Materials of the international remote scientific and practical conference, FSBSI "VNIIS n.a. Michurin", 73 (2013)

3. S.N. Stepanov, Clonal rootstocks in intensive gardening, coll. sc. works, Moscow, 7 (1973)

4. I.N. Pronina, R.D. Isaev, D.V., Sergeev, Proceedings of the All-Russian Scientific Research Institute of Horticulture n.a. I.V. Michurin, Sc. fundamentals of gardening, Col. of Sc. W., 160 (2005)

5. V.I. Budagovsky, Izvestiya AS USSR, 6, 11 (1954)

6. N.N. Gavrishov, V.V. Malychenko, A.Ya. Lobachev, T.G. Belyaeva, M.I. Vovk, Generalization of experience in the intensification of horticulture in the Volgograd region, 83, (1977)

7. V. M. Koshelenko, Clonal rootstocks in intensive gardening (1973)

8. S.N. Stepanov, Fruit Nursery (1963)

9. G.V. Trusevich, Rootstocks of fruit breeds, Moscow (1964)

10. E.A. Dolmatov, M.V. Kachalkin, A.V. Sidorov, T.A. Khrykina, Selection and variety breeding of garden crops (2014)

11. O.Yu. Emelyanova, A.M. Galasheva, E.N. Sedov, N.G. Krasova, E.Yu. Korolev, E.A. Dolmatov, et al., To preserve, replenish and study the gene pool of fruit, berry and ornamental plants in order to identify complex donors and sources of enes of economically valuable traits for the creation of new varieties (Research Report) (2018)

12. V.A. Korovin, Compatibility of apple tree scion and rootstock (1979)

13. O.N. Borisova, E.A. Dolmatov, Selection and variety breeding of garden crops, 3, (2), $6(2016)$

14. I.V. Semin, E.A. Dolmatov, Z.E. Ozherelyeva, Vegetables of Russia, 5, 75 (2020) 